\title{
Practical-Oriented Concept as a Principle of Professional Education of the Future Professionals
}

\author{
Nadiia Diachok ${ }^{1}$, Nadiia Chernukha ${ }^{2}$, Liudmyla Tokaruk ${ }^{2}$, Iuliia Udovenko² \& Mariana Mateeva Petrova ${ }^{3}$ \\ ${ }^{1}$ Borys Grinchenko Kyiv University, Ukraine \\ ${ }^{2}$ Taras Shevchenko National University of Kyiv, Ukraine \\ ${ }^{3}$ St.Cyril and St.Methodius University of Veliko Tarnovo, Bulgaria \\ Correspondence: Mariana Mateeva Petrova, St.Cyril and St.Methodius University of Veliko Tarnovo, Bulgaria.
}

Received: May 8, 2020

doi:10.5430/ijhe.v9n4p272
Accepted: June 22, 2020

Online Published: June 25, 2020

\begin{abstract}
The article considers the essence of the process of practice-oriented concept as a principle of the professional training quality of the future specialists. Socialization is singled out and considered through the interdisciplinary concept in professional education. Socialization is defined as a successful component of the future specialists' professional education. One of the ways of professional education of the future specialists is covered - participation in social projects of the higher education institutions. Emphasis is placed on the peculiarities of the socialization and professional education of the future specialists through the social project's organization. The motivational and innovative components of socialization in the professional education of future specialists are studied. The results of the experimental study are described.
\end{abstract}

Keywords: education, practice-oriented concept, socialization, professional education, interdisciplinarity of socialization, project, social project

\section{Introduction}

In modern society, a young professional faces the problem of self-determination, which is directly related to the question of his professional choice. Analyzing the scientific literature, we can conclude that consciously choosing a profession, the future specialist relies on their own knowledge about themselves (Uteubayev et al, 2018; Petrova et al, 2019; Jarmusevica et al, 2019). The current crisis of professions makes it possible to state that knowledge aboutone's "I" is insufficient for successful professional development. Therefore, recognizing this problem and finding a way to solve it successfully is an important vector for forming a successful professional.

Against the background of the study of one's own "I" should highlight the place of socialization of future professionals. In modern society, in particular professional, awareness of their own role in society is very important. This process involves: flexible adaptation to change in both the social and professional spheres; independent work on their own development (direction and content of professional activity); raising educational and cultural levels; rapid adaptation and integration into modern multinational society (Badjanova et al, 2020; Valdmane et al, 2020).

The position of G. Tard is correct, in his work is pointed out that the main mechanism of socialization is imitation, which is regulated by society through the education system, including education and upbringing, family, public opinion and other social institutions. According to the scientist, the main purpose of education is education and creation of conditions for development of the creative personality (G. Tard, 1902).

It should be noted that the professional socialization of future professionals in higher education institutions takes place in several ways. On the first - the choice of profession (life goals are determined, the prospects of obtaining a diploma in the relevant specialty); on the second - adaptation to the conditions of education in a higher education institution (adaptation to the conditions and content of the educational process, the formation of relations); the third way includes mastering the educational content and formation of practical skills (active student's interaction with the educational-professional environment, development of general-special abilities); the fourth way represents the result of higher education through the formation of professional identity (O. Pozhidayeva, 2015). 
It is indisputable that socialization during the education of future professionals is a complex and constant process of social relations' forming system. Accordingly, the system of socialization has a complex structure and is located at all stages of education in different ways.

The system of professional education in modern Ukraine is at the stage of change and search for new ways that will meet the requirements of modern society and its challenges (Zagorodnya et al, 2020; Nenkov et al, 2017; Petrova, Buzko \& Dyachenko, 2018; Bacho et al, 2019; Ghimire, 2020; Levashova, 2011A; Levashova, 2011A; Stemlewska, 2011). The relevance of our study is that solving the problem of socialization in the professional education of future professionals is associated with the resolution of certain contradictions between: professional socialization of future professionals and effective cooperation between social and educational sectors; growing needs for professional socialization and the lack of proper ways to socialize future professionals.

Given the above, we can state that the problem of socialization in professional education of the future professionals is currently poorly understood. To solve this problem requires to be concerted representatives' effort of different scientists' groups, theorists and practitioners. An extremely important place in this today is a practice-oriented concept of the professional training quality of the future specialists. One of the important vectors of successful use of practice-oriented concept in the professional education of the future professionals are social projects.

The purpose of the article is to highlight and substantiate the importance of the socialization process in the professional education of the future professionals through the use of social projects and practice-oriented concept.

Objectives of the study:

1) to analyze modern spheres of professional education of the future specialists;

2) to reveal the importance of a practice-oriented concept in the professional education of future specialists and to suggest ways to optimize their professional education.

\section{Analysis of the Research and Publications}

Socialization in the process of personal formation was studied by Kohlberg L. Tard G. for the consideration of "socialization" in science and made it possible to interpret this definition as the biological and individual psychological nature of man in the process of entering the hierarchically higher system - society.

When studying socialization in the professional education of future specialists, its interdisciplinary aspect should be singled out. Philosophy considers the process we study as a necessary phenomenon and condition for a person to fulfil his purpose as an individual, personality and individuality through interaction in the system of relations with other people (Aristotle, G. Hegel, K. Helvetius, L. Feuerbach). The peculiarity of this process, from the point of view of philosophy, is that socialization is influenced by the personal qualities of each individual.

In the context of sociology, human socialization is considered from two sides: as a process of the individual's adaptation to society under the influence of its institutions (Pozhydaieva O. Prokhorenko T., Savchenko S., Semigina T., Radul V.); as a process determined by the "dialogue of activities" of individuals, their inner needs, qualities, values (P. Blau, M. Weber, G. Garfinkel, F. Giddings, F. Znanetsky, C. Cooley, D. Mead, W. Thomas, D. Homans, A. Schutz).

About professional education of the future professionals, the study of socialization should be distinguished from the point of view of psychology and pedagogy. The first of them explores the phenomenon of interest to us as a process of the individual's immersion in society, the elimination of troubles and the search for satisfaction in the way of their own realization; as a result of change and creation of a new living space (K. Levin); as a way of moral formation of the personality taking into account moral canons of a society (Kohlberg, 1969).

Considering that another cross-cutting concept in this study is the professional education, it is worth considering the formation of professional socialization as a scientific concept. According to the scientist I. Sidorenko, professional socialization should be considered as a multifaceted, immersion's contradictory process of the individual in professional education. The scientist emphasizes that this stage is needed for the next stage: entering the country's labour arsenal (I. Sidorenko, 2012).

R. Shulygina in his scientific works argues that professional socialization in a higher education institution is a process of the individual's immersion in the professional environment, mastering the rules, norms and requirements of professional activity (R. Shuligina, pp. 1-9).

It is advisable to take into account that pedagogy reveals socialization as a process of involving the individual in the system of social relations, the formation of his social experience, formation and development as a whole person. In 
this case, pedagogy develops methods for the formation of certain social qualities and traits in all objects of pedagogical influence. Professional education of future specialists, in particular foreign language teachers, involves the process of socialization and distinguishes it as an influence's result of the team on the formation and development of personality. This process (formation and development of personality) includes a sequence of processes of adaptation, internalization, mobility in the process of transferring social experience through communication (Diachok N., 2019)

The process of socialization through a practice-oriented concept is impossible without public involvement. Public involvement is needed not only to assess the needs of the community, but also to agree on a problem-solving strategy. For example, the problem of unemployment in the local community can be solved in different ways - through retraining, resumption of closed production, promoting their own business and more. However, whatever the strategy, it must be feasible and acceptable, in particular, for representatives of local electoral authorities (Semigina TV, 2007).

It should be borne in mind that socialization occurs both in the educational process and in extracurricular activities (S. Savchenko, 2004). For the successful socialization of their students, higher education institutions of Ukraine have started organizing social projects. Organizing and conducting a social project is an innovative activity in the field of education. The purpose of a social project is to improve activities in a certain social stratum, the impact of which should always be positive in its social significance.

The modern educational space is characterized by increasing demands on the intellectual abilities and practical skills of future professionals, their ability to perceive the new changes according to the challenges of time. In practice, this indicates the need for targeted provision of professional education with a practice-oriented concept. The need of a practice-oriented concept is due to the development of society, and the need for rapid adaptation of specialists to modern conditions, and hence rapid socialization.

The importance of applying a practice-oriented concept in professional education is explained by the fact that the existing requirements of society to the effective operation of a competitive specialist do not coincide with the lack of their practical training.

Examining the interdisciplinary aspect of socialization we discovered that the phenomenon outlined by us is a process and result of successful assimilation and mobile reproduction of social experience (knowledge, values, norms, traditions) based on their own activities (communication, learning, work, play) and relationships implementation of various functions of all social institutions.

\section{Methods}

The theoretical and methodological basis of the study is an interdisciplinary practice-oriented concept to the study of the process of socialization and the educational's quality of the future professionals.

To solve the tasks used general scientific methods:

1) method of analysis and synthesis (in order to reveal the conceptual and categorical apparatus of research and scientific substantiation of the socialization process in the future professionals' education);

2) scientific abstraction, induction and deduction (summarizing domestic and foreign experience in the study of this issue);

3) abstract-logical (for theoretical generalization of research results and formulation of conclusions);

4) special methods: mathematical and statistical processing of research results (for survey analysis);

5) cross-tabulating and filtering results (for survey analysis);

5) comparative data (for survey analysis);

6) data analysis (for survey analysis);

7) systematization and differentiation (for survey analysis);

8) grouping, mean, standard deviation, regression, sample size determination, hypothesis testing (for survey analysis);

9) customized excel spreadsheets, graphic expression of data (for survey analysis).

The using of the different methods represent the resultant data that is collected from a sample of respondents that took a survey. This data is comprehensive information gathered from a target audience about a particular topic of interest to conduct research on the basis of this collected data. All methods allowed to obtain objective information 
about the process of socialization in the education of future professionals and the use of practice-oriented as a principle of professional education of the future professionals. The results of the study are presented using diagrams, tables and figures.

\section{Results Analysis}

For the practical significance of our theoretical research, a survey was conducted using the "Google Survey" system among students of the Kyiv Borys Grinchenko University and the Taras Shevchenko National University of Kyiv. The purpose of this survey was to identify the number of students who participated in social projects; identification of the number of students working in the speciality of study after participating in a social project. Students of III and IV courses of the first (bachelor) educational level also students of I and II courses of the second (master) educational level took part in the survey. The total number of respondents was 63 people, including 44 students of the first (bachelor) educational level and 19 people of the second (master) educational level.

The total number of respondents was 126 people, at the pilot test included 44 students of the first (bachelor) educational level and 19 people of the second (master) educational level; the final test included 35 students of the first (bachelor) educational level and 28 people of the second (master) educational level;

The main goal of the statistical survey was to find out the quantity of the students who participate in a social project after getting an information about it.

Research questions:

1 How many students are known about social projects?

2 How many students are participated in a social project?

3 How many students will participate in a social project after getting some information about it?

Hypothesis of our survey.

$\mathrm{H}_{0}$ : Students who participate in a social project after getting an information is not greater than in the other group.

$\mathrm{H}_{1}$ : Students who participate in a social project after getting an information is greater than in the other group.

The reaction of the respondents to some questions from the questionnaire turned out to be quite interesting for us. For example, to the question "Do you know what social projects are carried out on the basis of your higher education institution?" we obtained the following data (Figure 1).

\section{Social projects based on higher education institutions}

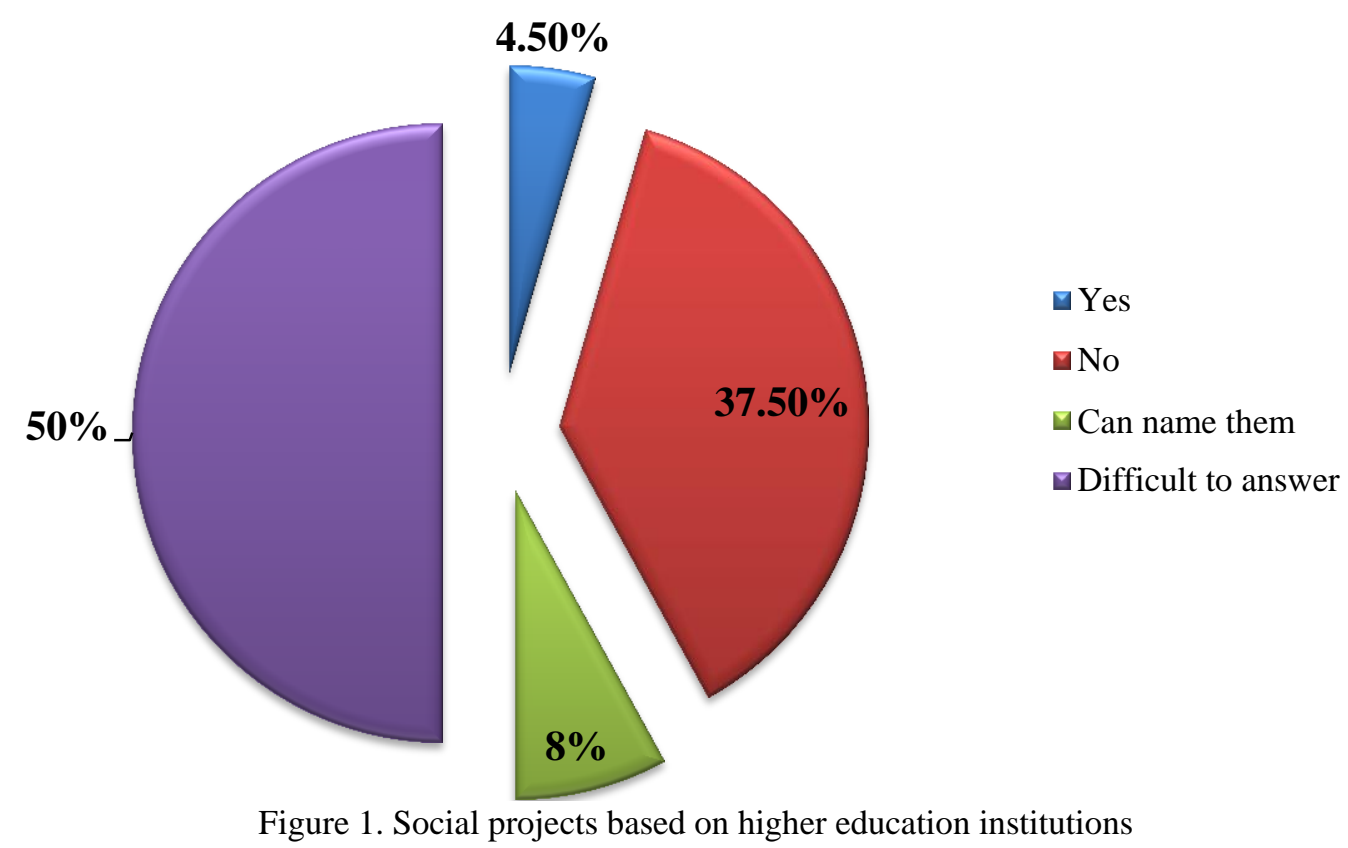

Created by the authors 
One of the main research questions was "Will students participate in a social project after getting some information about it?". The result of the pilot survey is that Bachelors aren't going to participate in social projects in average more than $60 \%$.

According to the results of the research, exactly half of the surveyed students (31 people) are not aware that annual social projects take place on the territory of their higher education institution. The need to inform students about social projects is relevant today. A fairly large percentage of ignorance is due to the fact that $75 \%$ (33 people) who do not know about the annual social projects are students of the first (bachelor) level of education

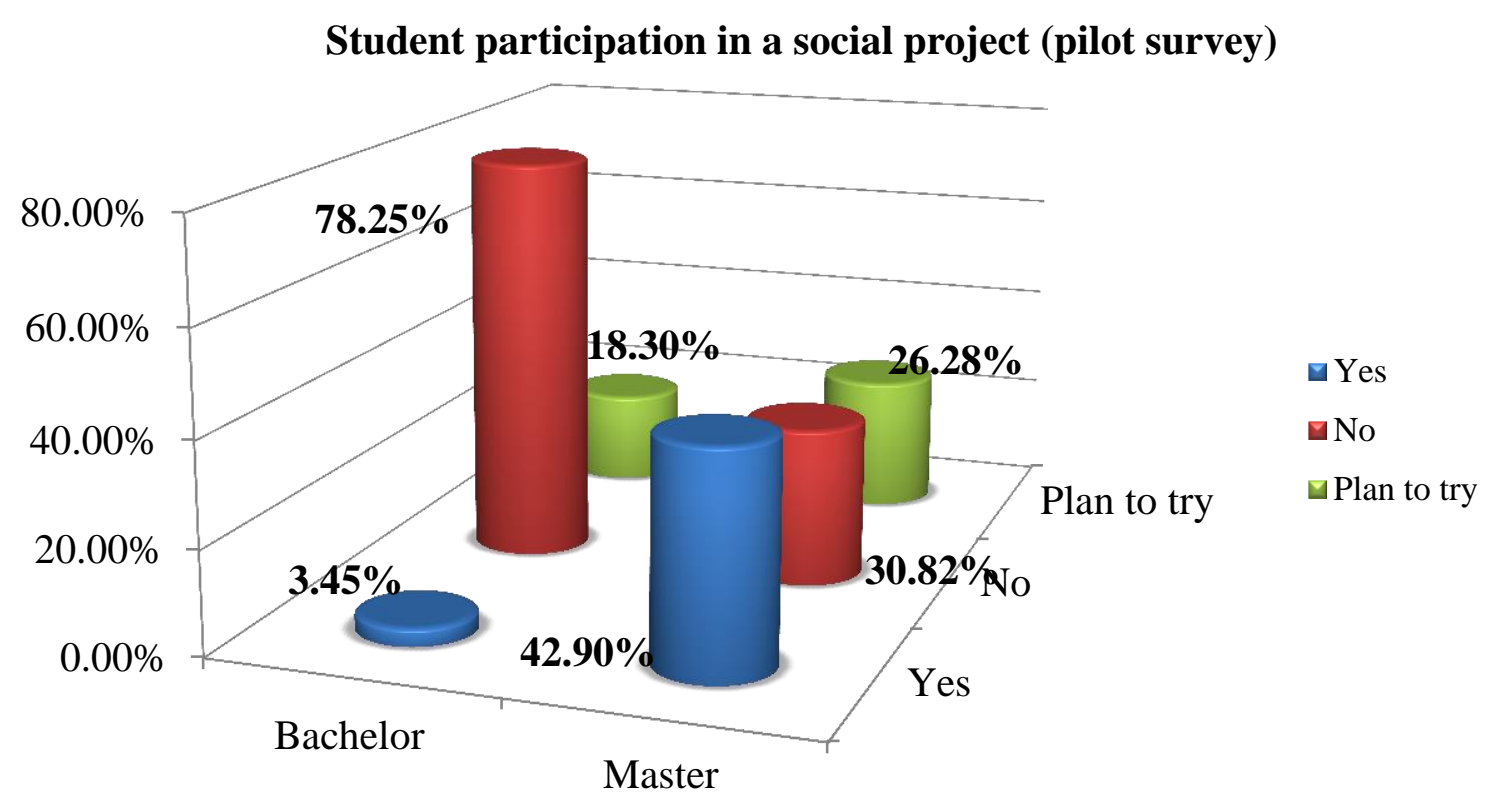

Figure 2. Student participation in a social project (pilot survey)

Created by the authors

When asked "Did you participate in the social project", the following statistics were obtained: at the first (bachelor) educational level, the number of students who participated in the social project is $3.45 \%$ of all respondents; Unfortunately, $78.25 \%$ of all surveyed students at the first (bachelor) level did not participate in social projects.

\section{Participation in a social project student of the first educational level}

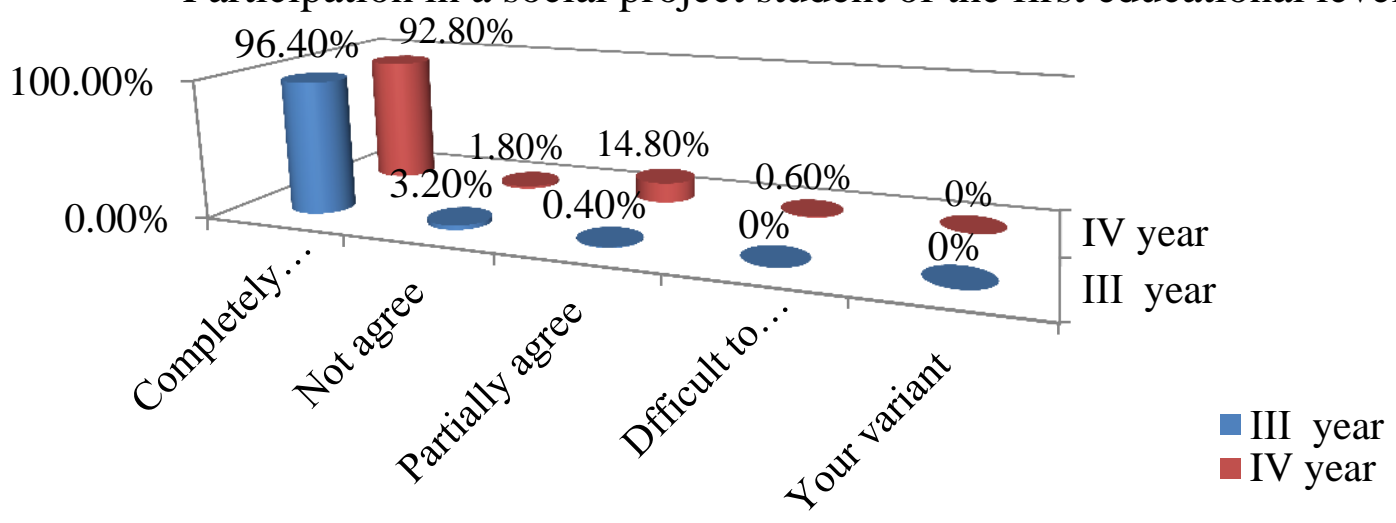

Figure 3. The result of participation in a social projectstudent of the first (bachelor) educational level

Created by the authors 
A positive fact is that the emergence of the students' desire to try their forces at organizing of the social project (18.3\%). Students of higher education institutions who did not participate and do not plan to do it is 59,95\% (at the first (bachelor) level). Because of the reasons, such as: lack of proper information training by higher education institutions

As for the students of the second (master's level), the situation is clearer here $-42.9 \%$ of students took in social projects, $30.82 \%$ - were not active in this activity. The last percentage is occupied by foreign students who do not speak Ukrainian at the appropriate level for organizing or conducting a social project. (Figure 2)

One of the key questions of our questionnaire was the following: "Did participating in a social project help you overcome fear and get a job in your specialty?" The answers of the respondents were also quite interesting, for example (Fig. 3, Fig.4).

\section{Participation in a social project student of the second educational level}

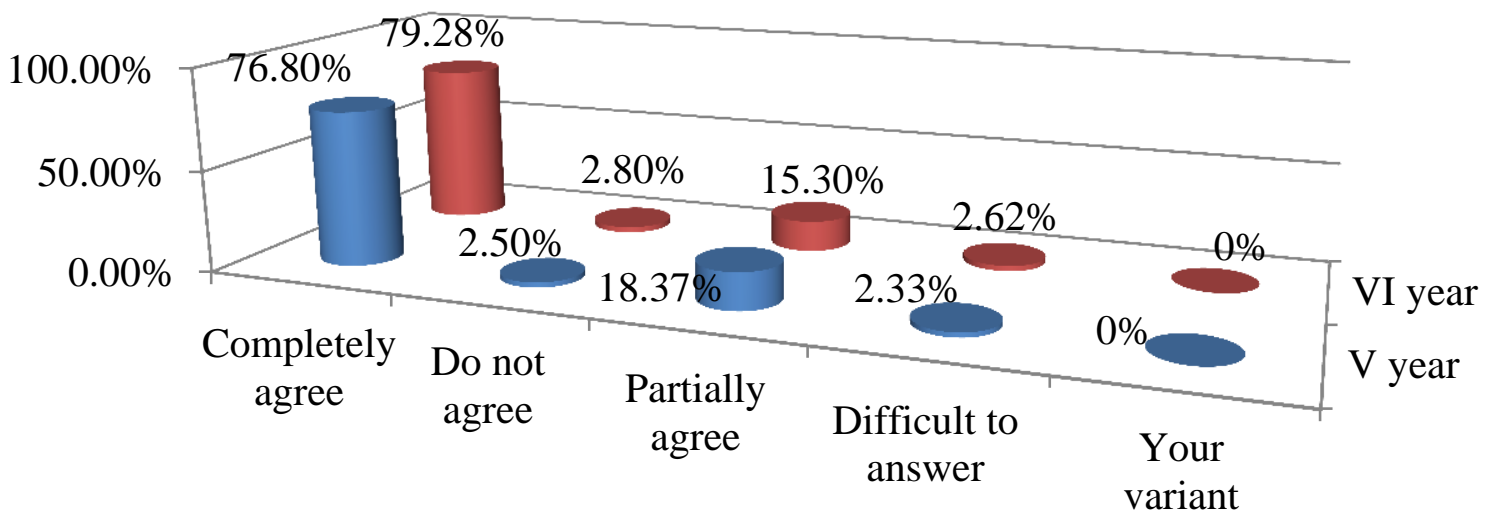

V year $\square$ VI year

Figure 4. The result of participation in a social project students of the second (master's) educational level Created by the authors

In average more than $90 \%$ of respondents at the first (bachelor) level and more than $75 \%$ of respondents at the second (master) educational level agreed that participation or organization of a social project helped students to socialize. No more than 3.5 percent at both levels of education denied this fact, due to the lack of employment in the chosen specialty of study.

When we talk about statistics of the final survey, we should say, it has changed. For example, the desire to participate in social project for better socialsation has increased.

Table 1 . The desire to participate in social project

\begin{tabular}{|c|c|c|c|}
\hline \multirow{2}{*}{\multicolumn{4}{|c|}{ Pilot survey }} \\
\hline & & & \\
\hline & Yes & No & Will try \\
\hline B & $3.45 \%$ & $78.25 \%$ & $18.30 \%$ \\
\hline M & $42.90 \%$ & $30.8 \%$ & $26.28 \%$ \\
\hline \multicolumn{4}{|c|}{ Final survey } \\
\hline & Yes & No & Will try \\
\hline B & $87.92 \%$ & $1.68 \%$ & $10.4 \%$ \\
\hline $\mathbf{M}$ & $84.68 \%$ & $1.72 \%$ & $13.6 \%$ \\
\hline \multicolumn{4}{|c|}{ Odds } \\
\hline B & $+84.47 \%$ & $-76.57 \%$ & -7.9 \\
\hline $\mathbf{M}$ & $+\mathbf{4 1 . 7 8 \%}$ & $-29.08 \%$ & $-12.68 \%$ \\
\hline
\end{tabular}

Created by the authors 
After getting detailed information on the topic of our research, the number of students who understand the importance of the social project for the process of professional socialization and realized the importance of socialization for successful personal self-development has increased.

For assessing the significance of differences between the two samples' percentages in which the effect of interest is registered we used Fisher's test.

Table 2. Fisher's test's table

\begin{tabular}{llll}
\hline \multirow{2}{*}{ Groups } & Is an effect & Is no effect & \multirow{2}{*}{ SUM } \\
\cline { 2 - 3 } B & Quantity & Quantity & \\
\cline { 2 - 3 } M & $44(55.7 \%)$ & $35(44.3 \%)$ & $49(100 \%)$ \\
& $19(40.4 \%)$ & $28(59.6 \%)$ & $47(100 \%)$ \\
\hline
\end{tabular}

Created by the authors

\section{Axis of significance}

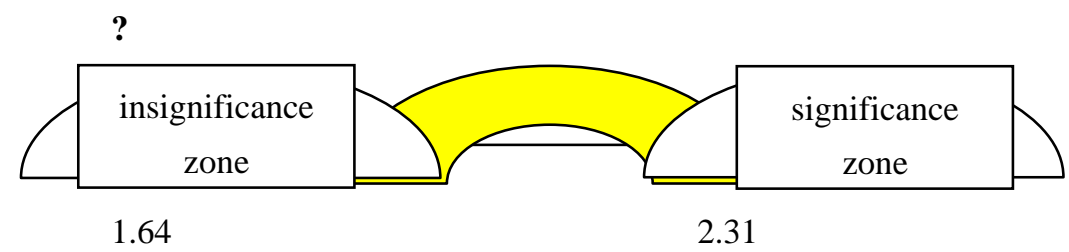

Answer $\varphi^{*}{ }_{\text {эмп }}=1.667$

Figure 5. Axis of significance

\section{Created by the authors}

The obtained empirical value of $\varphi *$ is in the zone of uncertainty. So we can reject $\mathrm{H} 0$

The obtained results represent that the professional training of future specialists requires higher education institutions takes into account the modern laws of the educational process, in particular the practice-oriented concept.

The use of social projects in the practical training of future professionals creates all the necessary conditions for full socialization of the specialist before their professional activity starting. Involvement of students in the organization and conducting of social projects implements the general, fundamental, innovative and practical functions of professional education. The implementation of these functions ensures the full socialization of future employees.

\section{Results and Discussions}

Exploring the socialization and practice-oriented concept in professional education of future professionals, it is necessary to pay attention to changes in the emphasis on flexibility and speed of response of professional education to the requirements of the modern labour market. We can say that the priority vector of education of future professionals is to ensure the labour potential of society. This process establishes the cooperation of employees in the field of education, the main task of which is both the modernization of educational outcomes and the actual improvement of education system. On the other hand, it should be noted that the solution to this problem should strengthen internal ties throughout the education system, and therefore, to form a competitive specialist and independence of their own work in this field

The application of the practice-oriented concept in professional education really implements the combination of cognitive, theoretical and practical components of education. Moreover, cognitive components do not create a system of industrial, technological, humanitarian, legal and innovative knowledge, but also create an internal culture, forming the readiness of future professionals to consciously harmonize the relationship "man - society - nature - education".

The article emphasizes that socialization in professional education appears as a result of development and formation of personality, as social control over production activities is inevitable in the process of socio-professional formation, that's why the use of practice-oriented concept in professional education is necessary. This will form an effective and successful specialist for the modern labour market.

The use of various specialists from abroad in higher education institutions, gives students the opportunity to successfully use their knowledge and skills: 
1) general theoretical - professional skills;

2) practical and applied - to expand the practical component of professional activity;

3) organizational - to update the system of self-education;

4) socialization - the use of adaptation of the future specialist to the modern labor market.

Effective use of skills by future professionals involves the introduction of innovative activities in higher education institutions, due to the need for socialization of future professionals. The importance of the practice-oriented concept in the professional education of students lies in the effective use of theoretical knowledge acquired during the educational process in practice.

Given the above, we consider it necessary to identify existing socio-educational projects that are aimed at the socialization of future professionals with direct participation in them.

The charitable organization "International Charitable Foundation" directs its activities to help socialize orphans, graduates of boarding schools, adolescents and young people who are in difficult life circumstances. In particular, through the implementation of the following programs: "Mentoring" (carry out the selection of mentors individually for each child from boarding schools); "Adaptation and socialization programs for boarding school graduates"; "Programs to support families in difficult life circumstances to save the children of a biological family"; "Support for adolescents who are at risk and need help", etc. (Charitable organization "International Charitable Foundation” Maximum “).

In autumn 2017, a pilot project was launched by the AIKEN International Charitable Foundation, which provides social support to children and young people in difficult life circumstances by promoting the development of social entrepreneurship focused on the development of inclusion in Ukraine and job creation for people with special needs, members of their families (AIKEN International Charitable Foundation).

Since the beginning of 2019, the Project on Social Work with Families and Children has been implemented by the Charitable Organization "I am Near" Charitable Organization with the support of the Commissioner of the President of Ukraine for Children's Rights Mykola Kuleba. The project aims to support families with children who are in situations of vulnerability, difficult life circumstances and to develop the ability of parents to care for their children. Within the framework of this project the practices of the centres for work with children and families in different regions of Ukraine were studied, as a result of which the development of the Basic model of the day centre for children and families is being completed and will be tested ("I'm here").

Every year, from mid-autumn, the social project "With Kyiv and for Kyiv" continues its work at the Kyiv Borys Grinchenko University. Residents of the city are invited to attend: computer courses, interest clubs, consultations, training sessions; creative circles, studios, concert programs, competitions, health programs. Representatives of social categories are free to attend classes within this project. Social categories eligible for free social project: pensioners, children of anti-terrorist operation fighters, as well as children whose parents died during hostilities in the environmental protection zone or as a result of injuries; citizens who have the status of immigrants; veterans of the Great Patriotic War; orphans and children deprived of parental care; persons with disabilities; children from low-income families; children from large families (5 and more people under 18) (Kyiv Borys GrinchenkoUniversity, Social project).

The School of Social Leadership is represented on the basis of the Taras Shevchenko National University of Kyiv within the framework of the social project. The aim of this project is to create an environment for the development and support of talented and socially active student youth capable of designing and implementing social change in Ukraine. The main tasks of the "School of Social Leadership" are such as: promoting the development of social responsibility of participants as a basis for social leadership; developing the ability of participants to activate community resources as a counterweight to the principle of "social dependence"; promoting the formation of an active life position, awareness of social responsibility for themselves and the future of their country (Taras Shevchenko National University of Kyiv, School of Social Leadership).

Participation in social projects becomes important not only for the population of Kyiv and the whole of Ukraine, but also for students who take part in social projects under the close supervision of their teachers. The social project is one of the factors of successful socialization in professional education through a practice-oriented concept as a principle of professional education of the future specialist and provides opportunities for students to realize their creative and personal needs. 
The socialization of future professionals is a consequence of the application of practice-oriented concept involves the development of cognitive skills of all participants, the ability to navigate in the information space, use the acquired knowledge in practice, forms the ability to independently design their own activities. Thus, the involvement of students in social projects involves purposeful bilateral socialization of all participants.

Since in the article the concept oriented to practice is singled out as the principle of professional education of the future specialist, we will say that the most effective approach focused on practice is realized during multi-vector social projects. It is social projects that create conditions for the maximum participation of future professionals in real problems in the socialization of different age groups, as well as in the challenges of modern society.

\section{Conclusions}

According to the results of the study, the following conclusions can be drawn. The necessity of using practical-oriented concept in the educational institutions leads to socialization forming of the future specialist.

We should base educational process on socio-humanitarian and general educational didactic principles, using the traditional type of teaching with a predominance of explanatory, illustrative and problem-developing teaching, while the dominant types of training are lectures and seminars, but we mustn't forget about practical part of the professional education. The practical part of the professional education leads to the formation of successful socialization.

It has been proved that at higher educational institutions the socialization of future specialists during professional education with the using practice-oriented context as a principle of professional education of the future specialist is carried out in several stages.

At the same time, verbal-visual-practical teaching methods prevail at higher education institutions of Ukraine, distance education system is mainly practiced as an auxiliary, for the purpose of students' self-education, and insufficient material, technical and information-computer equipment limits the ability to successful formation of the future specialists in the educational process of higher educational institutions.

To solve this problem, we propose to use the technology of social and educational projects in the educational process of higher education arises from a practice-oriented concept of the socialized specialist's formation. Participation in social projects provides a practical component of a student's professional education, determining the socio-professional purpose of his activities. Thus, the socialization of specialists during their professional education forms the social activity of the future specialist. The process under study during professional education takes into account the formation of professional and world-view qualities, the acquisition of theoretical professional knowledge, the formation of practical skills, the formation of professional values and orientations, the acquisition of new social roles by overcoming uncertainty about the chosen profession.

However, the undertaken study does not exhaust the fullness of the problem of using practical-oriented concept in professional education. Further research requires such important aspects of the problem as the analysis of the influence of social projects for specialists in the humanitarian and technical sectors in the modern labour market.

\section{References}

Bacho, R., Pukala, R., Hlibko, S., Vnukova, N., Pola, P. (2019). Information Management: the Key Driver of the Economic System's Development. Marketing and Management of Innovations, 3, 297-307. http://doi.org/10.21272/mmi.2019.3-23

Badjanova J., Iliško Dz., Ignatjeva Sv., Petrova M., Gorbunovs A. (2020). Evaluation and analysis of personality traits of Latvian and Bulgarian Inhabitants. International Conference on Natural Sciences and Humanities (ICONSH'20), 30-31 March, 2020, in Athens, Greece (inprint).

Diachok, N. V. (2019). The professional mobility formation of the future language teachers in the educational environment of the university. Candidate's thesis (Theory and Methods of Vocational Training). Kyiv.

Duginets, G., Petrova, M. (2020). THE ESSENCE OF HYBRID WARS IN THE XXI CENTURY. Professional competencies and educational innovations in the knowledge economy: collective monograph / Ed: Lyubomira Popova, Mariana Petrova. Veliko Tarnovo, Bulgaria: Publishing House ACCESS PRESS, 2020. -552 p. ISBN 978-619-91511-0-5, 174-189. http://access-bg.org/ebooks

Ghimire, R.P. (2020). Scientific Enquiry into the Flat Social Media Innovation based Modelling of Flat Social Entrepreneurship for Economic and Non-Economic Opportunities. Access journal, 1(1), 31-38. https://doi.org/10.46656/access.2020.1.1(2)

Jarmusevica, V.; Ilisko, D.; Badjanova, J.; Jukss, V.; Petrova, M. (2019). Educating citizens for implementing the 
strategy of corporate social responsibility for sustainable regional development: the case study. Proceedings of EDULEARN19 Conference 1st-3rd July 2019, Palma, Mallorca, Spain, ISBN 978-84-09-12031-4, 10449-10454. https://doi.org/10.21125/edulearn.2019.2633

Kohlberg, L. (1969). Stage and sequence: The cognitive development approach to socialization. In D. A. Goslin (Ed.). Handbook of socialization theory (347-480). Chicago, IL, Rand McNally.

Kyiv National Taras Shevchenko University, School of Social Leadership [Electronic resource] // Access mode: http://www.psy.univ.kiev.ua/ua/previews/751-shkola-sotsialnoho-liderstva (accessed:08/05/2020)

Kyiv Borys Grinchenko University. Social project [Electronic resource] // Access mode: https://kubg.edu.ua/prouniversitet/sotsialnyi-proekt/sotsialnyi-proekt.html

https://kubg.edu.ua/prouniversitet/sotsialnyi-proekt/sotsialnyi-proekt.html (accessed:08/05/2020)

Levashova, L. (2011A). Marketing wewnętrzny w kontekście motywowania pracowników, w: Świerszcz K. i Nowacki $W$., Ksztaltowanie lojalności klientów w teorii $i$ w praktyce. Warszawa: Wydawnictwo Warszawska Wyższa Szkoła Ekonomiczna.

Levashova, L. (2011B). Rozwój kariery zawodowej pracowników $w$ aspekcie innowacji, w: Innowacje przedsiębiorstw a satysfakcja klientów w teorii $i$ w praktyce, pod redakcja naukowa Świerszcz K. $i$ Śliwa J. Warszawa: Wydawnictwo Społeczna Wyższa Szkoła Przedsiębiorczosci i Zarządzania w Łodzi.

Nenkov N., Dyachenko Y., Petrova M., Bondarenko G. \& V. Pustovit. (2017). Intelligent and Cognitive Technologies in Education of International Economic Relations Students and Human Resource Development in Enterprises: Methodology in Language. European Journal of Sustainable Development, 6(4), 353-360. https://doi.org/10.14207/ejsd.2017.v6n4p353

Petrova M.,Buzko I, Dyachenko Yu. (2018). Cognitive, Intelligence Technologies and Economical Foundations of Teaching of International Economical Relations and Tourism. 17th International Scientific Conference ERDev, 23.-25.05.2018. Jelgava, latvia, 1102-1106. https://doi.org/10.22616/ERDev2018.17.N170

Petrova, M., Tepavicharova, M., Dikova, L. (2019). Factors for development of the educational and professional qualification profile of the human resources in the machine building sector in Bulgaria. ISPCIME-2019. MATEC Web of Conferences, 297 (06015). https://doi.org/10.1051/matecconf/201929706001

Pozhydaieva, O. (2015). Professionalsocializationoffuturesocialpedagoguesinhighschoolenvironment [in Russ]. Collection of scientific works of Kamyanets-Podilsky National University named after Ivan Ogienko, (24), October 2015, 139-144.

Prokhorenko T.G. (2019). Features of professional socialisation of youth in conditions of globalisation [in Ukrainian]. Bulletin of the Yaroslav the Wise National University of Law, 4, 8-13. https://doi.org/10.21564/2075-7190.43.188028

Radul V. (2011). The features of pfofessional socialization of individuality [in Ukrainian]. Scientific Bulletin of the Nikolaev State University named after Sukhomlinsky V. O., 1(1), 33, November 2011, 66-70.

Savchenko S., Kurylo V. (2019). Media Socialization as a Component of Personality Socialization in the Information Society [in Ukrainian].Bulletin of Taras Shevchenko Lviv National University, 1(1), March 2019, 83-89. https://doi.org/10.12958/2227-2844-2019-1(324)-1-83-89

SemiginaT. V. (2007). Social planning model on the local level [in Ukrainian]. Scientific works. Pedagogical, psychological sciences and social work, 59, 61-66.

Shuligina R. A. Features of professional socialization of student youth in the educational space of the university [in Ukrainian]. [Electronic resource] // Access mode: https://ird.npu.edu.ua/files/shulygina.pdf (accessed:08/05/2020)

Stemplewska, L. (2011). Wpływ otoczenia ekonomicznego na efektywność systemów motywacyjnych $w$ przedsiębiorstwach. Warszawa: Wydawnictwo Elipsa.

Tard G. (1902). Social Etudes.

Uteubayev, T., Petrova M.M., Lyubenova, I. (2018). Training of qualified specialists in the process of their education at the university: the role of the public-private partnership. CBU International Conference Proceedings 2018: Innovations in Science and Education, 491-495. https://doi.org/10.12955/cbup.v6.1203

Valdmane, L., Zarina, S., Iliško, D., Badjanova, J., Petrova, M. (2020). Empowering of Digital and media literacy of 
primary school teachers in Latvia. EDULEARN20,12th annual International Conference on Education and New Learning Technologies, 6th - 7th of July, 2020 (inprint).

Zagorodnya, A., Dichek, N., Chobitko, N., Voznyk, M., Honchar, L., Petrova, M. (2020). Professional training of the economic sector specialists at higher education institutions of the Republic of Poland and Ukraine: criteria of comparison. International Journal of Higher Education, 9(3), 139-144. https://doi.org/10.5430/ijhe.v9n3p139 